\title{
KEWENANGAN PENYIDIK TNI ANGKATAN LAUT DALAM MEMBERANTAS TINDAK PIDANA PELAYARAN DI WILAYAH NEGARA KESATUAN REPUBLIK INDONESIA
}

\author{
Galih Umbara \\ Anggota TNI Angkata Laut \\ e-mail: Ujangumbara7@gmail.com
}

\begin{abstract}
Abstrak-Penanggulangan tindak pidana pelayaran diatur dalam Undang-Undang Nomor 17 Tahun 2008 tentang Pelayaran. Salah satu kewenangan penegakan hukum di bidang pelayaran dimiliki oleh TNI Angkatan Laut. TNI Angkatan Laut mempunyai peran ganda yaitu menjaga kedaulatan wilayah laut serta menegakkan hukum yuridiksi nasional berdasarkan hukum nasional dan hukum Internasional. Permasalahan yang muncul meliputi bagaimana kewenangan TNI Angkatan laut dalam penyidikan tindak pidana pelayaran, serta bagaimana hambatan-hambatan yang dihadapi. Hasil penelitian menunjukkan bahwa seluruh institusi penegak hukum khususnya yang berwenang menangani perkara tindak pidana tertentu diwilayah perairan Indonesia, termasuk TNI Angkatan Laut, bertanggung jawab untuk melaksanakan tugasnya menanggulangi dan mengendalikan tindak pidana diwilayah perairan laut Indonesia. Bahwa dalam upayanya melakukan pemberantasan tindak pidana di wilayah laut, meskipun pemerintah telah melakukan berbagai upaya, seperti melalui kebijakan legislasi maupun dengan membentuk forum atau badan koordinasi. Hambatan-hambatan yang dihadapi oleh penyidik TNI Angkatan Laut meliputi berkaiatan dengan tidak adanya pembagian kewenangan antar aparat penegak hukum, tidak adanya koordinasi yang baik antar aparat penegak hukum, kurangnya sumber daya manusia aparat penegak hukum, serta sarana dan prasarana dalam penegakan hukum.
\end{abstract}

Kata Kunci: Kewenangan, Penyidikan, Tindak Pidana Pelayaran, TNI Angkatan Laut.

\begin{abstract}
The countermeasures of shipping crime is regulated by Law Number 17 the Year 2008 regarding Shipping. One of the authorities of law enforcement in the field of shipping is owned by TNI Navy. The Navy has a dual role of safeguarding the territorial sovereignty of the sea and upholding the law of the national jurisdiction under national law and international law. Problems that arise include how the authority of the Navy in the investigation of criminal acts of shipping, as well as how the obstacles faced. The results showed that all law enforcement institutions, especially those in charge of handling certain criminal cases in the territorial waters of Indonesia, including the Navy, are responsible for carrying out their duties to tackle and control criminal acts in the territorial waters of Indonesia. In the effort to eradicate criminal acts in the sea area, although the government has made various efforts, such as through legislation policy or by forming a forum or coordinating institution. The obstacles faced by TNI investigators include the lack of proper division of authority between law enforcement officers, the lack of good coordination among law enforcement officers, the lack of human resources in law enforcement officers, and the facilities and infrastructure in law enforcement.
\end{abstract}

Keywords: Authority, Investigation, Crime Sailing, Navy.

\section{A. PENDAHULUAN}


Negara Kesatuan Republik juga bertetangga dengan Korea Indonesia adalah negara kepulauan (archipelagic state) yang dipersatukan oleh wilayah lautan dengan luas seluruh wilayah teritorial adalah 8 juta $\mathrm{km}^{2}$, mempunyai panjang garis pantai mencapai 81.000 $\mathrm{km}$, hampir 40 juta orang penduduk tinggal di kawasan pesisir. Luas wilayah perairan mencapai 5,8 juta $\mathrm{km}^{2}$ atau sama dengan $2 / 3$ dari luas wilayah Indonesia. Terdiri dari Zona Ekonomi Eksklusif (ZEE) 2,7 juta $\mathrm{km}^{2}$ dan wilayah laut teritorial 3,1 juta $\mathrm{km}^{2}$ (www.mgi.esdm.go.id, 2017).

Indonesia memiliki wilayah perairan yang sangat luas, dengan keadaan fisik geografis Indonesia yang bertetangga dengan banyak negara. Negara tersebut berada dalam kawasan Asia Tenggara (ASEAN) maupun yang berada di luar ASEAN. Negara tersebut adalah Singapura, Malaysia, Thailand dan Indocina di sebelah utara, Australia di selatan, dan Timor Leste di timur. Tetangga yang lebih jauh adalah Selandia Baru, negara-negara Pasifik Selatan, dan kepulauan-kepulauan di Pasifik yang berada di bawah lingkungan kekuasaan Amerika Serikat. Di Utara

Selatan, Jepang, Taiwan, dan negara besar China di daratan Asia serta Bangladesh, Sri Langka, India dan Pakistan di Asia Selatan (Atje Misbach Muhjiddin, 1993:19).

Konsekuensi logis terhadap luasnya wilayah perairan Indonesia menimbulkan potensi kerawanan sengketa batas wilayah. Terdapat 12 batas wilayah perbatasan laut yang berpotensi menimbulkan sengketa batas wilayah selain blok Ambalat yaitu Pulau Rondo (dengan India), Pulau Berhala (dengan Malaysia), Pulau Mipal (dengan Singapura), Pulau Sekatung (dengan Vietnam), Pulau Marore, Pulau Miangas, dan Pulau Marampit (dengan Filiphina), Pulau Vani, Vanilda serta Pulau Bras (dengan Republik Palau), Pulau Batek (dengan Timor Leste), dan Pulau Dana (dengan Australia) (Arif Djohan Tunggal, 2008:45).

Dengan kondisi tersebut menjadikan Indonesia memiliki posisi yang terbuka sehingga dapat memberikan peluang bagi negara lain untuk masuk dan melakukan aktivitas di wilayah Indonesia dengan berbagai dampak dan akibat yang ditimbulkan. 
Dampak negatif yang mungkin terjadi adalah terjadinya konflik dengan berbagai kepentingan antara Indonesia dengan negara-negara tetangga maupun negara lain yang menggunakan daratan serta perairan Indonesia. Sehingga dapat menimbulkan ancaman yang potensial terjadi, berupa konflik di bidang politik maupun militer yang dapat mempengaruhi kedaulatan negara serta sistem politik, ekonomi, sosial, budaya dan hankam nasional.

Salah satu contoh ancaman adalah wilayah Kepulauan Natuna yang berpotensi menimbulkan konflik antarnegara. Hal ini dikarenakan Cina dan Vietnam masih mengklaim kepulauan itu sebagai wilayahnya (Arif Djohan Tunggal, 2008:45).

Konsep kedaulatan laut suatu negara menurut pendapat Bynkershoek melalui bukunya De Domino Maris Desertatio memperingatkan kepada semua negara yang memiliki wilayah laut bahwa kedaulatan suatu negara di laut sangat tergantung kepada kemampuan negara tersebut melakukan pengawasan secara fisik terhadap wilayah laut yang dikuasai
(Syamsumar Dam, 2010:11). Indonesia mempunyai $60 \%$ lautan dari seluruh wilayah kedaulatan negara sangat rentan terhadap ancaman dari luar maupun keamanan wilayah laut. Dengan wilayah laut yang sangat luas menjadikan Indonesia rentan terhadap tindak pidana perompakan, illegal fishing, illegal mining, terorisme, peredaran gelap narkotika, maupun pencemaran lingkungan.

Tentara Nasional Indonesia Angkatan Laut sebagai komponen utama pertahanan negara di laut mempunyai tugas dan peran ganda yaitu sebagai institusi pertahanan kedaulatan negara dan institusi penegak hukum di laut. Pasal 9 Undang-Undang Nomor 34 Tahun 2004 tentang Tentara Nasional Indonesia disebutkan bahwa tugas pokok TNI Angkatan Laut yaitu Pertama, melaksanakan tugas Tentara Nasional Indonesia matra laut di bidang pertahanan. Kedua, menegakkan hukum dan menjaga keamanan di wilayah laut yurisdiksi nasional sesuai dengan ketentuan hukum nasional dan hukum internasional yang telah diratifikasi. 
Ketiga, melaksanakan tugas Ditjen Kementrian Kelautan dan diplomasi Angkatan Laut dalam Perikanan, PPNS Ditjen Hubla rangka mendukung kebijakan politik Kementrian Perhubungan, PPNS luar negeri yang telah ditetapkan oleh pemerintah. Tugas diplomasi TNI Angkatan Laut (naval diplomacy) adalah fungsi diplomasi sesuai dengan kebijakan politik luar negeri yang melekat pada peran Angkatan Laut secara universal sesuai dengan kebiasaan internasional, serta sudah menjadi sifat dasar dari setiap kapal perang suatu negara yang berada di negara lain memiliki kekebalan diplomatik dan kedaulatan penuh. Keempat, Melaksanakan tugas TNI dalam pembangunan dan pengembangan kekuatan matra laut. Kelima, Melaksanakan pemberdayaan wilayah pertahanan laut.

Keamanan di laut tidak dapat dilaksanakan oleh institusi TNI AL secara mandiri tetapi juga melibatkan institusi dan lembaga lain. Instansi yang berwenang menangani tindak pidana di laut meliputi Kepolisian RI, PPNS Kementrian Kesehatan, PPNS Ditjen Bea Cukai Kementrian Keuangan, PPNS Kementrian Kehutanan, PPNS Ditjen Imigrasi Kementrian Hukum dan HAM, PPNS

PPNS Kementrian Kebudayaan dan Pariwisata serta Bakamla.

Pelibatan instansi lain ini dalam perkembangannya sering menghadapi berbagai kendala dan masalah. Kendala-kendala yang dihadapi misalnya terkait masalah kewenangan penyidikan, yuridiksi penyidikan, penanganan tersangka dan barang bukti, bahkan masalah perawatan dan pelelangan barang bukti. Selain itu penegakkan hukum di laut banyak melibatkan berbagai unsur atau instansi lain karena luasnya wilayah laut yuridiksi nasional serta pembagian/pengaturan zona wilayah laut yang berbeda-beda (UNCLOS, 1982). Kompleksitasnya permasalahan di laut juga dikarenakan adanya dua aturan hukum yaitu hukum nasional dan hukum internasional.

Penyidik masing-masing instansi tersebut mempunyai tugas dan tanggung jawab sendiri-sendiri, akan tetapi dalam fakta di lapangan masih terjadi sengketa kewenangan 
penyidikan. Hal ini disebabkan berbagai hal baik terkait dasar hukumnya (legal standing) maupun substansi tindak pidana tersebut. Konflik kewenangan penegakkan hukum ini menurut Lufsiana adalah masing-masing instansi berwenang dalam menanganai perkara yang sama dan berjalan sendiri-sendiri tanpa adanya keterpaduan sistem dalam pelaksanaannya, artinya sama-sama berwenang melakukan penyidikan tanpa adanya pembagian kewenangan secara tegas dan jelas tanpa adanya mekanisme kerja yang pasti (Lufsiana, 2008:395). Hal ini disebabkan oleh lemahnya sistem hukum itu sendiri.

Tindak pidana pelayaran adalah tindak pidana yang terkait dengan aktifitas pelayaran. Pelayaran adalah satu kesatuan sistem yang terdiri atas angkutan di perairan, kepelabuhanan, keselamatan dan keamanan, serta perlindungan lingkungan maritim. Penanganan tindak pidana pelayaran bersifat khusus sehingga berlaku asas lex spesialis derogat legi generalis. Kekhususannya antara lain terkait dengan hukum formalnya, pertanggungjawaban pidananya, serta instansi yang berwenang dalam penyidikannya. Kewenangan penyidikan tindak pidana pelayaran dimiliki oleh beberapa instansi yaitu PPNS Ditjen Perhubungan Laut Kementrian Perhubungan, Kepolisian RI, serta Perwira TNI Angkatan Laut. Berdasarkan Pasal 282 ayat (1) Undang-Undang Nomor 17 Tahun 2008 tentang Pelayaran disebutkan bahwa selain penyidik Pejabat Polisi Negara Republik Indonesia dan penyidik lainnya, pejabat pegawai negeri sipil tertentu di lingkungan instansi yang lingkup tugas dan tanggung jawabnya di bidang pelayaran diberi wewenang khusus sebagai penyidik sebagaimana dimaksud dalam Undang-Undang ini. Pengertian penyidik lain dalam penjelasan pasal tersebut adalah penyidik sesuai dengan ketentuan peraturan perundang-undangan antara lain Perwira Tentara Nasional Indonesia Angkatan Laut. Kewenangan penyidikan yang dimiliki oleh TNI Angkatan Laut bersifat independen atau mandiri sedangkan kewenangan penyidikan oleh PPNS di lingkungan Perhubungan Laut tetap berada di 
bawah koordinasi dan pengawasan penyidik POLRI.

Selain itu dasar kewenangan TNI Angkatan Laut sebagai aparat penegak hukum diperkuat dalam BAB XX tentang Ketentuan lain-lain terutama pada Pasal 340 UndangUndang Nomor 17 Tahun 2008 tentang Pelayaran yang menyebutkan bahwa "Kewenangan penegakan hukum pada perairan Zona Ekonomi Eksklusif dilaksanakan oleh Tentara Nasional Indonesia Angkatan Laut sesuai dengan ketentuan peraturan perundang-undangan”. Peraturan perundang-undangan yang dimaksud adalah Pasal 13, 14, dan 15 Staatblad 1939 Nomor 442 tentang Ordonansi Laut Teritorial dan Lingkungan Laut Larangan (TZMKO atau Territtorial Zee en Maritime Kringen Ordonantie), Pasal 14 ayat (1) Undang-Undang RI Nomor 5 Tahun 1983 tentang Zona Ekonomi Ekslusif Indonesia (ZEEI) serta Pasal 224 Undang-Undang Nomor 17 Tahun 1985 tentang Pengesahan Konvensi Perserikatan Bangsa-bangsa Tentang Hukum Laut (United Nations Convention on the Law of the Sea/UNCLOS).
Penyidikan tindak pidana pelayaran sebagai bagian dari penegakan hukum di laut mempunyai ciri-ciri atau cara-cara yang khusus (lex specialis) dan mengandung beberapa perbedaan dengan pemeriksaan tindak pidana yang terjadi pada umumnya. Misalnya berkaitan dengan penentuan locus delicti. Pada tindak pidana di laut tidak mengenal locus delicti. Hal ini disebabkan karena di laut terdapat bukan saja kepentingan nasional, akan tetapi terdapat pula kepentingankepentingan internasional yang harus dihormati, seperti hak lintas damai (right of innocent passasge), hak lintas alur laut kepulauan, hak lintas transit, pemasangan kabel laut serta perikanan tradisional negara tetangga. Berdasarkan uraian tersebut, dapat disimpulkan bahwa di satu sisi TNI Angkatan Laut bertugas menjaga kedaulatan dan keutuhan wilayah laut yuridiksi nasional. Di sisi lain TNI Angkatan Laut mempunyai kewenangan dalam menegakkan hukum di laut berdasarkan hukum nasional dan hukum internasional berupa, pengejaran, penyelidikan, serta penyidikan tindak pidana 
pelayaran. Dengan demikian, penulis merasa tertarik untuk mengkaji dan menganalisis kewenangan TNI Angkatan Laut dalam menegakkan hukum di laut. Harapan penulis untuk meneliti tema ini adalah untuk menganalisis kewenangan yang dimiliki oleh Penyidik Perwira TNI Angkatan Laut dalam menegakkan hukum serta memberantas tindak pidana pelayaran yang berada di wilayah yuridiksi nasional.

Permasalahan yang muncul meliputi bagaimana kewenangan TNI Angkatan laut dalam penyidikan tindak pidana pelayaran, serta bagaimana hambatan-hambatan yang dihadapi oleh penyidik TNI Angkatan Laut?

\section{B. HASIL DAN PEMBAHASAN}

1. Kewenangan Penyidik TNI Angkatan Laut Terkait Sinkronisasi Koordinasi Antara Penyidik TNI Angkatan Laut Dengan

\section{Lembaga Penyidik Lainnya}

Dalam rangka wemujudkan tujuan negara sebagaimana tercantum dalam alenia keempat pembukaan Undang-Undang Dasar Negara
Republik Indonesia Tahun 1945 yakni melindungi segenap bangsa Indonesia dan seluruh tumpah darah indonesia, memajukan kesejahteraan umum, mencerdaskan kehidupan bangsa, dan melaksanakan ketertiban Dunia, maka negara berkewajiban melaksanakan pembangunan nasional dengan aman, damai, adil, dan demokratis. Guna mewujudkan kondisi yang aman dan damai, upaya pengamanan dan penegakan hukum di wilayah perairan laut menjadi sangat penting dan strategis untuk dilaksanakan, sebagaimana yang tertuang dalam penjelasan umum Undang-Undang Nomor 31 Tahun 2004 Tentang Perikanan. Wilayah kesatuan Indonesia yang sebagian wilayahnya berupa perairan, TNI Angkatan Laut memegang peranan yang besar dalam melakukan pengamanan dan penjagaan diwilayah perairan laut, dimana secara universal TNI Angkatan Laut memiliki tiga peran yaitu peran militer, peran polisionil, dan peran diplomasi, hal ini sebagaimana dinyatakan dalam Undang-Undang Nomor 34 Tahun 2004 tentang TNI yang menegaskan bahwa TNI Angkatan Laut bertugas 
melaksanakan tugas di bidang pertahanan, menegakan hukum dan menjaga keamanan di wilayah laut yurisdiksi nasional, serta melakukan diplomasi angkatan laut. Oleh karena itu, TNI Angkatan Laut dituntut untuk mampu melaksanakan peran dan tugasnya secara maksimal dalam rangka menegakan kedaulatan dan hukum diwilayah laut. Sebagai upaya untuk upaya pengamanan dan penegakan hukum di wilayah perairan laut indonesia terdapat tiga instansi yang berwenang yang masing-masing didukung oleh undang-undang tersendiri.

Keadaan yang demikian ini menimbulkan tumpang tindih (overlapping) kewenangan dalam bidang penyidikan terhadap tindak pidana tertentu yang terjadi diwilayah perairan laut, hal ini mengakibatkan ketidakefektifan upaya pemberantasan tindak pidana diwilayah perairan laut apabila penegakan hukum ditangani oleh instansi terkait secara sektoral tanpa ada koordinasi. Oleh karena itu untuk menjamin kepastian hukum diperlukan metode penegakan hukum yang bersifat spesifik dengan pembagian kewenangan yang jelas sehingga masing-masing instansi dapat menjalankan kewenanganya tanpa memunculkan egosektoral.

Pada saat ini kita ketahui bahwa, TNI AL merupakan salah satu bagian utama dari sistem pertahanan negara Indonesia di wilayah perairan yang mempunyai kewajiban untuk menjaga keutuhan dan kedaulatan negara serta integritas wilayah NKRI, mempertahankan stabilitas keamanan di laut, melindungi sumber daya alam di laut dari berbagai bentuk gangguan keamanan dan pelanggaran hukum di wilayah perairan yurisdiksi nasional Indonesia. Adapun konsepsi dasar terhadap perwujudan keamanan di laut pada hakikatnya memiliki dua dimensi yaitu penegakan kedaulatan dan penegakan keamanan yang saling berkaitan satu dengan lainnya (Bernard Kent Sondakh, 2004).

Secara Yuridis Formal menurut berbagai peraturan perundangundangan yang berlaku, khususnya yang mengatur mengenai, Tentara Nasional Indonesia, wilayah perairan laut indonesia, maupun mengenai tindak pidana tertentu diwilayah perairan laut indonesia, bahwa TNI 
Angkatan Laut memiliki wewenang dan kewajiban untuk melakukan penegakan hukum diwilayah perairan laut indonesia yang terbatas dalam lingkup pengejaran, penangkapan, penyelidikan, dan penyidikan yang selanjutnya diserahkan kepada kejaksaan untuk dilakukan proses penuntutan, hal ini sebagaimana di nyatakan dalam penjelasan pasal 9 huruf $\mathrm{b}$ Undang-Undang Nomor 34 Tahun 2004 tentang Tentara nasional Indonesia. Selain itu dalam pasal 17 Peraturan Pemerintah Nomor 27 Tahun 1983 tentang Pelaksanaan KUHAP beserta penjelasannya.

Dengan demikian secara yuridis formal, bahwa kewenangan TNI Angkatan Laut dalam Melakukan Penegakan Hukum diwilayah Perairan laut tidak diragukan lagi. Sesuai dengan ketentuan hukum serta dengan mengingat tugas daripada TNI AL khususnya dalam bidang penegakan hukum, maka TNI AL sangat berkewajiban dan berkepentingan dalam melaksanakan dan melakukan penegakan hukum diwilayah perairan laut guna mennciptakan keamanan dan ketertiban.
Walaupun telah dilaksanakan upaya-upaya dalam pemberantasan tindak pidana diwilayah perairan laut, akan tetapi permasalahan mengenai keamanan wilayah laut tetap menjadi persoalan yang harus segera dipecahkan yang salah satunya disebabkan oleh masih tingginya intensitas tindak pidana diwilayah perairan laut. Oleh karena itu guna meningkatkan efektivitas penanganan tindak pidana diwilayah perairan laut supaya tercipta keamanan dan ketertiban perlu dilakukan optimalisasi peran TNI Angkatan Laut khususnya dalam bidang penegakan hukum.

\section{Dalam Pasal 9 Undang-undang} Nomor 34 Tahun 2004 telah disebutkan dengan jelas mengenai tugas pokok TNI AL. Apabila kita fokuskan pada tugas TNI AL pada point kedua seperti tersebut di atas maka usaha menegakkan hukum dan menjaga keamanan di laut yurisdiksi nasional adalah segala bentuk kegiatan yang berhubungan dengan penegakkan hukum di laut sesuai dengan kewenangan TNI AL (contabulary function) yang berlaku secara universal dan sesuai dengan 
ketentuan perundang-undangan yang berlaku untuk mengatasi ancaman tindakan kekerasan, ancaman navigasi, serta pelanggaran hukum di wilayah laut yurisdiksi nasional. Dengan demikian tugas pokok TNI AL selain bidang pertahanan di laut juga menyelenggarakan keamanan laut bagi penggunanya. Pelaksanaan tugas TNI AL dalam bidang keamanan laut, tidak hanya terfokus pada penegakkan hukum di laut, karena keamanan laut mengandung pengertian bahwa laut bisa dikendalikan dan aman digunakan oleh pengguna untuk bebas dari ancaman atau gangguan terhadap aktifitas pemanfaatan laut.

Sebagai salah

satu penyelenggara keamanan di laut maka TNI AL berhak menyidik perkaraperkara (tindak pidana) tertentu yang terjadi di laut, hal ini sesuai dengan undang-undang (dasar hukum) yang berlaku. Dalam melaksanakan tugasnya sebagai penyelenggara keamanan di laut TNI AL selalu beriringan dan bekerjasama serta berkoordinasi dengan institusi dan lembaga baik internasional maupun nasional yang terkait. Menyadari hal- hal tersebut di atas dan kompleksnya masalah di laut.

Oleh sebab itu tegaknya, keamanan di laut tidak mungkin hanya dilaksanakan oleh institusi TNI AL saja secara mandiri tetapi juga melibatkan institusi dan lembaga lain. Berbagai usaha yang telah dilakukan TNI AL dalam melaksanakan penyelenggaraan keamanan di laut melalui rangkaian kegiatan patroli, penyidikan dan penindakan berdasarkan peraturan perundangundangan nasional dan Hukum Laut Internasional terhadap segala bentuk pelanggaran hukum di laut serta melaksanakan pengamanan obyek vital nasional di laut. Adapun beberapa upaya yang dapat dilakukan guna mengoptimalkan peran TNI Angkatan Laut dalam usaha pemberantasan tindak pidana diwilayah perairan laut. Sebagaimana ditegaskan dalam Undang-Undang Dasar Negara Republik Indonesia Tahun 1945, bahwa negara Indonesia merupakan negara hukum, yang mengatur segala segi kehidupan dalam suatu peraturan perundangundangan, oleh karena itu segala tindakan pemerintahan termasuk 
dalam bidang penegakkan hukum juga harus berdasarkan pada aturan hukum yang jelas sebagai implementasi daripada asas legalitas.

Secara hukum instansi yang diberi wewenang melakukan penegakan hukum diwilayah perairan laut berwenang untuk membuat aturan hukum yang bersifat regulasi dalam menjalankan kewenangannya untuk menegakkan hukum, hal ini sebagaimana diatur dalam UndangUndang Nomor 10 Tahun 2004 tentang Pembentukan Peraturan Perundang-undangan. Dengan mengingat asas legalitas UndangUndang Nomor 10 Tahun 2004, maka pembetukan peraturan internal mengenai standar operasional dan prosedur penanganan Tindak Pidana oleh TNI Angkatan Laut penting untuk segera dilakukan oleh TNI Angkatan laut

(http://Artikelcakrawala/search/TN

I-AL/).

Meskipun telah terjadi
kemajuan dalam penangan tindak
pidana diwilayah perairan laut,
namun hal itu hanya terbatas pada
penangan tindak pidana perikanan,
sedangkan permasalahan keamanan

diwilayah laut lebih luas daripada bidang perikanan. Oleh karena itu guna meningkatkan efektivitas penanganan tindak pidana diwilayah perairan laut oleh TNI Angkatan Laut, perlu dibuat peraturan internal yang bersifat regulasi mengenai standar operasional dan prosedur penanganan Tindak Pidana diwilayah perairan laut sebagai dasar tindakan hukum bagi penyidik TNI Angkatan Laut.

Sebagaimana kita ketahui bahwa terdapat tiga instansi yang berwenang melakukan penegakan hukum diwilayah perairan laut, dimana kewenangan ketiga instansi ini diatur secara khusus tersendiri dalam berbagai peraturan perundangundangan. Dimana keadaan yang demikian ini menimbulkan tumpang tindih (overlapping) kewenangan dalam bidang penyidikan terhadap tindak pidana tertentu yang terjadi diwilayah perairan laut. Adapun tumpang tindih kewenangan ini dapat mengakibatkan ketidakefektifan upaya pemberantasan tindak pidana diwilayah perairan laut apabila penegakan hukum ditangani oleh instansi terkait secara sektoral tanpa 
ada koordinasi serta sangat potensial untuk menimbulkan konflik kewenangan dalam penegakan hukum.

Dalam upaya pengamanan dan penegakan hukum di wilayah perairan laut Indonesia terdapat tiga instansi yang berwenang yang masing-masing didukung oleh undang-undang tersendiri, ketiga instansi tersebut yakni:

a. Kepolisian Negara Republik indonesia, dimana berdasarkan pasal 13 dan 14 huruf g Undangundang No. 2 Tahun 2002 tentang Kepolisian Negara Republik Indonesia, bahwa kepolisian berwenang melakukan penyidikan terhadap semua tindak pidana sesuai dengan hukum acara pidana dan peraturan perundang-undangan lainya.

b. TNI Angkatan Laut, dimana berdasarkan Pasal 9 UndangUndang Nomor 34 Tabun 2004 tentang TNI, menyatakan bahwa selain melaksanakan tugas di bidang pertahanan, TNI Angkatan Laut juga bertugas menegakan hukum dan menjaga keamanan di wilayah laut yurisdiksi nasional.
Disamping itu dalam Pasal 17 Peraturan Pemerintah Nomor 27 Tahun 1983 tentang Pelaksanaan KUHAP beserta penjelasannya ditegaskan bahwa penyidikan dalam perairan Indonesia, zona tambahan, landas kontinen dan zona ekonomi eksklusif Indonesia, dilakukan oleh Perwira TNI Angkatan Laut dan penyidik lainnya yang ditentukan oleh undang-undang yang mengaturnya.

c. Pegawai Negeri Sipil (PPNS), dimana berdasarkan pasal 6 ayat (1) huruf b KUHAP, yang dimaksud dengan penyidik adalah pejabat kepolisian dan penyidik pegawai negeri sipil yang diberi wewenang khusus oleh undangundang. Selain itu Wewenang penyidik pegawai negeri sipil dalam melakukan penyidikan tindak pidana diwilayah perairan laut juga secara tegas dinyatakan dalam berbagai peraturan perundang-undangan yang mengatur baik mengenai wilayah perairan laut indonesia maupun mengenai tindak pidana tertentu diwilayah perairan laut. 
Guna meningkatkan efektivitas penanganan tindak pidana diwilayah perairan laut, perlu adanya keseragaman pola tindak dan harmonisasi antara ketiga instansi tersebut, oleh karena itu koordinasi menjadi kunci keberhasilan pemberantasan tindnak pidana diwilayah perairan laut. Berkaitan dengan kerjasama lintas sektoral ini, pemerintah telah membentuk badan koordinasi keamanan laut yang mempunyai tugas pokok mengkoordinasikan penyusunan kebijakan dan pelaksanaan kegiatan operasi keamanan laut secara terpadu. Meskipun telah ada badan koordinasi, tetapi dalam pada kenyataanya pelaksanaan koordinansi ini berjalan tidak optimal, hal dapat tercermin dari penanganan dan penyelesaian tindak pidana diwilayah perairan laut.

\section{Hambatan-Hambatan Yang} Dihadapi Penyidik TNI Angkatan Laut Dalam Memberantas Tindak Pidana Pelayaran Di Wilayah Negara Kesatuan Republik Indonesia

Upaya TNI Angkatan Laut ketika melaksanakan kegiatan penegakan hukum tindak pidana di bidang pelayaran banyak sekali menemukan permasalahan. Permasalahan tersebut pada gilirannya akan menghambat dan mengurangi efektifitas kinerja sebagaimana yang telah diamanatkan oleh Undang-Undang Nomor 17 Tahun 2008 tentang Pelayaran. Adapun hambatan-hambatan terhadap pelaksanaan penegakan hukum tindak pidana di bidang pelayaran yang terjadi di wilayah Negara Kesatuan Republik Indonesia, penulis akan menganalisa melalui pendekatan dengan mengadopsi pemikiran Friedman mengenai sistem penegakan hukum yang meliputi struktur hukum, subtansi hukum dan budaya hukum.

a. Hambatan Struktur Hukum

Hambatan yang terkait struktur hukum dapat diartikan yaitu hambatan yang menyangkut aspek legal formal yang menjadi dasar kewenangan tersebut diberikan serta tata cara bekerjanya keseluruhan instansi-instansi penegak hukum. Struktur hukum dapat dikatakan sebagai institusi yang menjalankan penegakan hukum dengan segala proses yang 
berlangsung di dalamnya Jadi hambatan yang bersifat kelembagaan instansi aparat penegak hukum (law enforcement officer) yang meliputi:

1) Kurangnya koordinasi antara aparat penegak hukum (law enforcement officer) di lapangan. Hal ini dibuktikan dengan belum adanya persamaan persepsi tentang penegakan keamanan di laut yang diimplementasikan dalam bentuk penegakan kedaulatan dan penegakan hukum di laut. Penegakan hukum (law enforcement) di laut terkesan adanya ego sektoral masingmasing intansi.

2) Tidak adanya fasilitas tahanan pelaku tindak pidana tertentu dilaut. Ketika berbicara mengenai peran polisionil yang dimiliki oleh TNI Angkatan Laut maka seharusnya sarana dan prasarana pendukungnya harus tersedia dengan baik. Sampai dengan saat ini seluruh Pangkalan TNI Angkatan Laut dari Sabang sampai Merauke tidak mempunyai rumah tahanan bagi tersangka tindak pidana tertentu di laut.

3) Ketidakmandirian penyidik TNI Angkatan Laut. Bagi setip aparat penegak hukum TNI Angkatan laut dalam melaksanakan tahapan-tahapan penyelidikan atau penyidikan harus melakukan pelaporan dan persetujuan ke komando atas. Hal ini jelas merupakan campur tangan tangan pimpinan dalam proses yustisial.
4) Keterbatasan sarana dan prasarana penegakan hukum tindak pidana pelayaran. Kebutuhan sarana prasarana berupa kapal patroli merupakan kebutuhan mutlak dari upaya penegakan hukum di laut.

5) Minimnya dukungan logistik. Dukungan logistik berupa BBM dirasa sangat kurang sekali sehingga banyak KRI/KAL tidak beroperasi secara maksimal. Operasi dilakukan hanya berkala pada waktu yang telah ditentukan.

6) Tidak adanya anggaran untuk penyidikan. Pada tahap penyidikan memerlukan banyak anggaran misalnya untuk permohonan saksi ahli, permohonan penetapan geledah sita ke Pengadilan Negeri, biaya perawatan kapal yang sedang menunggu proses hukum, dan lain-lain.

7) Sumber daya Manusia (Human resources). Hal ini penyangkut kualitas penyidik TNI Angkatan laut yang kurang memadai. Penyidik TNI Angkatan laut tidak semua mempunyai kualifikasi sarjana hukum atau setidak-tidaknya menguasai teknik dan taktik penyidikan di laut (R. Soesilo, 1980:57).

8) Rendanya mental aparat penegak hukum (law enforcement officer). Permasalahn besar bangsa Indonesia saat ini adalah rendahnya kualitas integritas moral serta etika aparat penegak hukum (law enforcement officer) termasuk penegakan di bidang pelayaran (www.analisadaily.com, 2017) 
b. Hambatan Terkait Dengan Substansi Hukum

Hambatan yang berasal
substansi hukum yang meliputi
materi perundang-undangan yang
mengatur tentang penegakan
hukum di bidang pelayaran.
Substansi hukum (legal substance)
adalah aturan, norma dan pola
perilaku nyata manusia yang
berada di dalam sistem tersebut.
Substansi hukum juga berarti
produk yang dihasilkan oleh
orang-orang yang berada di dalam
sistem hukum itu, baik berupa
keputusan yang mereka keluarkan,
maupun juga aturan-aturan baru
yang mereka susun. Hambatan
yang paling menonjol yaitu
menyangkut peraturan perundang-
undangan yang tidak konsisten
sehingga mempengaruhi dalam
pelaksanaan penegakan hukum.
Hambatan-hambatan tersebut
antara lain:

1) Kurang tegasnya peraturan dan perundangan yang ada, karena masih terdapat beberapa peraturan dan perundangan yang tumpang tindih sehingga mengakibatkan penafsiran hukum yang berbeda. Hal ini terkait dengan kewenangan penyidikan tindak pidana pelayaran yang dimiliki oleh 3 (tiga) instansi yaitu POLRI, PPNS Perhubungan Laut, serta Perwira TNI Angkatan Laut.

2) Terlalu banyaknya peraturanperundangan di bidang pelayaran. Banyaknya aturan hukum yang ditetapkan menyulitkan bagi pemakai laut itu sendiri terutama bagi tansportasi tradisional yang kurang paham terhadap peraturan di bidang pelayaran. Aparat penyidik TNI Angkatan Laut terkadang tidak mengerti atas perubahan-perubahan tentang dokumen-dokumen kapal karena peraturan perundangannya mengacu kepada konvensi internasional tentang kepelautan. Peraturan tentang pelayaran berasal dari produk hukum nasional karena menyangkut yuridiksi hukum nasional, dan juga adanya konvensi-konvensi internasional tentang pelayaran yang harus juga ditaati oleh pengguna laut di dunia.

3) Tidak adanya ketentuan khusus yang mengatur jangka waktu penangkapan. Tindak pidana pelayaran merupakan tindak pidana khusus dan harus menggunakan hukum acara pidana yang khusus juga. Terkait lamanya penangkapan seseorang yang diduga melakukan tindak pidana pelayaran dalam undangundang pelayaran tidak diatur secara jelas. Jika mengacu pada KUHAP terutama dijelaskan Pasal 19 ayat (1) menyatakan penangkapan dapat dilakukan 
Galih Umbara, Kewenangan Penyidik Tni Angkatan Laut Dalam Memberantas...

untuk paling lama satu hari. Pertanyaan muncul ketika KRI menangkap kapal yang diduga melakukan tindak pidana pelayaran di tengah laut dan untuk sampai ke pangkalan membutuhkan waktu lebih dari satu hari. Hal ini yang sering mendapat upaya hukum pra peradilan dari tersangka/terdakwa.

c. Hambatan Terkait Dengan Budaya Hukum

Budaya hukum sebagai sikap manusia (dalam hal ini masyarakat) terhadap hukum dan sistem hukum itu sendiri. Sikap masyarakat ini menyangkut kepercayaan, nilai-nilai dan ideide, serta harapan mereka tentang hukum dan sistem hukum. Budaya hukum merupakan bagian dari budaya umum masyarakat. Budaya hukum mempunyai peranan yang besar dalam sistem hukum, sehingga tanpa budaya hukum, maka sistem hukum akan kehilangan kekuatannya, seperti ikan mati yang terkapar di kerancangnnya, bukan ikan hidup yang berenang di lautan (without legal culture, the legal system is inert-a dead fish lying in a basket, not a living fish swimming in its sea). Hambatan yang terkait dengan budaya hukum adalah lemahnya kesadaran masyarakat terhadap penegakan hukum. Penyuluhan dan sosialisasi regulasi tentang pelayaran kurang mampu meningkatkan kesadaran masyarakat. Masyarakat nelayan cenderung tidak peduli/terhadap sistem hukum yang ada terutama di bidang pelayaran. Contoh konkritnya adalah pada tahap penyelidikan dan penyidikan masyarakat enggan memberikan informasi terkait dugaan terjadinya tindak pidana pelayaran. Masyarakat sebagian besar beranggapan bahwa pemberian informasi akan menyulitkan masyarakat sendiri ke depannya. Dikhawatirkan akan banyak regulasi yang mengatur masyarakat tersebut sehingga akan mengurangi mata pencahariannya.

Sebagaian masyarakat tersebut resisten terhadap perkembangan perkembangan pelayaran. Misalnya banyaknya peraturan yang justru dianggap akan menghambat kinerja mereka sendiri. Pandangan-pandangan 
semacam ini pada akhirnya justru menghambat proses penegakan hukum itu sendiri. Pola pikir semacam ini dipengaruhi oleh beberapa faktor, misalnya:

1) Tingkat pendidikan, kepedulian dan kesadaran masyarakat masih relatif rendah. Seharusnya masyarakat pesisir mampu menjadi mata dan telinga bagi aparat penegak hukum artinya apabila melihat telah terjadi tindak pidana di bidang perikanan segera memberi informasi kepada aparat penegak hukum. Namun tidak demikian di lapangan, sehingga tidak membantu dan ada kesan acuh tidak peduli apa yang terjadi di lingkungannya;

2) Pendidikan dan berbagai kursus-kursus yang pernah diikuti belum dilaksanakan secara baik dan benar. Artinya para pelaku pelayaran di Indonesia telah menerima tetapi tidak dilaksanakan atau bahkan terlambat dalam mengikuti perkembangan-perkembangan yang ada.

3) Hukum lebih banyak berperan sebagai alat represif aparat penegak hukum dalam penegakan hukum. Sebenarnya cara-cara yang prefenstif sebenarnya lebih bisa menjadi sarana proses penegakan hukum.

4) Masih lemahnya komitmen dari pihak pemerintah baik di tingkat pusat maupun di daerah dalam menata regulasi hukum terutama bagi masyarakat kecil. Sehingga para pelaku tindak pidana pelayaran banyak dilakukan oleh masyarakat menengah ke bawah.

\section{SIMPULAN}

1. Kewenangan TNI Angkatan Laut dalam penanggulangan tindak pidana bersumber pada konsep pokok peran hakiki yang dimiliki oleh TNI Angkatan Laut secara Universal, sebagai bagian utama dari kekuatan laut secara universal TNI Angkatan Laut mengemban tiga peran yang disebut dengan "Trinitas Peran Angkatan Laut", yaitu peran militer, peran diplomatik, dan peran polisionil. Kemudian seluruh institusi penegak hukum khususnya yang berwenang menangani perkara tindak pidana tertentu diwilayah perairan Indonesia, termasuk TNI Angkatan Laut, bertanggung jawab untuk melaksanakan tugasnya menanggulangi dan mengendalikan tindak pidana diwilayah perairan laut Indonesia. Bahwa dalam upayanya melakukan 
Galih Umbara, Kewenangan Penyidik Tni Angkatan Laut Dalam Memberantas...

pemberantasan tindak pidana di wilayah laut, meskipun pemerintah telah melakukan berbagai upaya, seperti melalui kebijakan legislasi maupun dengan membentuk forum atau badan koordinasi.

2. Hambatan-hambatan yang dihadapi oleh Penyidik TNI Angkatan Laut adalah:

a. Hambatan struktural, meliputi kurangnya koordinasi antaraparat penegak hukum (law enforcement officer) di lapangan, tidak adanya fasilitas tahanan tindak pidana pelayaran yang dimiliki oleh TNI Angkatan Laut, Ketidakmandirian penyidik TNI Angkatan Laut, keterbatasan sarana dan prasarana penegakan hukum tindak pidana pelayaran, minimnya dukungan logistik serta anggaran untuk penyidikan, kurangnya kualitas sumber daya manusia (Human resources) bagi penyidik TNI Angkatan Laut serta rendanya mental aparat penegak hukum (law enforcement officer).

b. Hambatan terkait dengan substansi hukum, meliputi; kurang tegasnya peraturan dan perundangan yang ada, terlalu banyaknya peraturanperundangan di bidang pelayaran, tidak adanya ketentuan khusus yang mengatur jangka waktu penangkapan.

c. Hambatan terkait dengan budaya hukum, meliputi rendahnya kesadaran masyarakat dalam membantu proses penegakan hukum.

\section{SARAN}

1. Perlu adanya perubahan regulasi yang tegas terkait pemberian kewenangan penyidikan tindak pidana pelayaran. Perundangan yang ada saat ini belum mampu memberikan solusi untuk penegakan hukum tindak pidana pelayaran. Hal ini dikarenakan terdapat tiga instansi yang berbeda akan tetapi mempunyai 
wewenang dan kedudukan yang yang sama. Akibatnya sering terjadi konflik kepentingan dan terkesan penegakan hukumnya bersifat ego sektoral.

2. Membenahi segala hambatan baik yang bersifat substansi, struktural serta kultural. Terkait hambatan yang bersifat struktural adalah peningkatan kualitas sumber daya manusia aparat penyidik TNI Angkatan Laut serta peningkatan anggaran dalam pelaksanaan penegakan hukum di laut. Peningkatan kualitas penyidik TNI Angkatan Laut melalui pelatihan, kursus-kursus, dan latihan gabungan untuk meningkatkan profesionalitas dan integritas aparat penyidik.

\section{DAFTAR PUSTAKA}

Arif Djohan Tunggal, Hukum Laut (Suatu Pengantar), Harvarindo, Jakarta, 2008.

Atje Misbach Muhjiddin, Status Hukum Perairan Kepulauan Indonesia dan Hak Lintas Kapal Asing, Alumni, Bandung, 1993.

Bernard Kent Sondakh, Pengamanan Wilayah Laut Indonesia,
Fakultas Hukum Universitas Indonesia, Jurnal Hukum Internasional, Jakarta, 2004.

Lufsiana, Konflik Kewenangan Penegakan Hukum Perikanan, Cakrawala, 2008.

R. Soesilo, Taktik dan Teknik Penyidikan Perkara Kriminil, Politea, Bogor, 1980.

Syamsumar Dam, Politik Kelautan, Bumi Aksara, Jakarta, 2010.

Undang-Undang RI Nomor 17 Tahun 1985 tentang Pengesahan Konvensi Perserikatan Bangsabangsa Tentang Hukum Laut (United Nations Convention on the Law Of the Sea/UNCLOS).

Undang-Undang Nomor 2 Tahun 2002 tentang Kepolisian Negara Republik Indonesia.

Undang-Undang Nomor 34 Tahun 2004 tentang Tentara Nasional Indonesia.

Undang-Undang Nomor 17 Tahun 2008 tentang Pelayaran.

Undang-Undang RI Nomor 1 Tahun 2014 Tentang Perubahan Atas Undang-Undang Nomor 27 Tahun 2007 tentang Pengelolaan Wilayah Pesisir dan Pulau-Pulau Kecil.

Lufsiana, Konflik Kewenangan Penegakan Hukum Perikanan, http://Artikelcakrawala/search/ TNI-AL/. 
Galih Umbara, Kewenangan Penyidik Tni Angkatan Laut Dalam Memberantas...

Pusat Penelitian dan Pengembangan

Geologi Kelautan Morfologi

Dasar laut Indonesia, dikutip

dari

http://www.mgi.esdm.go.id/con

tent/morfologi-dasar-laut-

indonesia/

Opini, Menyorot Kualitas Moral Penegak Hukum, dikutip dari http://www.analisadaily.com/ne ws/read/2011/12/10/. 